\title{
Exploitation of Cold Plasma Technology for Enhancement of Seed Germination
}

\author{
Rohit Thirumdas* \\ Food Engineering \& Technology department, Institute of Chemical Technology, India
}

Submission: October 01, 2017; Published: January 09, 2018

"Corresponding author: Rohit Thirumdas, Food Engineering \& Technology department, Institute of Chemical Technology, Mumbai-400019, India, Tel: +91-8879183895; Email: ft12rr.thirumdas@pg.ictmumbai.edu.in

\begin{abstract}
Cold plasma is an emerging non thermal technology primarily used for microbial disinfection and surface modification. The principle of plasma surface modification is exploited in food and agriculture for enhance of seed germination and other reasons. The aim of the present review is to give some insights on cold plasma technology exploitation for enhancement of seed germination. The seed germination rate can be increased on application of cold plasma by both direct and indirect treatments. Recently, the indirect treatment through the application of plasma activated water (PAW) has drawn some attentions. The formation of reactive oxygen species and reactive nitrogen species in the plasma are mainly responsible for increase in seed germination rate. Of all those reactive species formed in the PAW, the nitrate ions severe as the fertilizer and NO radical breakdown dormancy which enhanced the seed germination rate. The synergistic effect of cold plasma can replace the traditional seed disinfection solutions and chemical seed germination enhancers.
\end{abstract}

Keywords: Seed; Germination; Cold plasma; Plasma activated water; Reactive species

\section{Introduction}

The present human population statistic says that the population of the earth reached to about 7.6 billion. It is insufficient for the total cultivable land to meet the demand of increasing population consumption. In order to meet this demand, the only way is to increase the crop yields. Enhancing the seed germination rate and draught resistant seeds is the best way to improve crop production. The most commonly used methods to enhance the seed germination are the chemical methods (agrochemicals, fungicides, insecticides and hormones). But these types of treatments leave chemical residues which are harmful to the human health and environment. Therefore, it is necessary to develop new alternative technologies to enhance seed germination to keep up with pace of growing population. Filatova et al. [1] reported that the non thermal and electromagnetic technologies have been successfully applied to enhance the seed germination. Cold plasma is one of such technologies recently drawn interest in food and agriculture sector.

Plasma is known as the fourth state of matter, charged gas with strong electrostatic interactions. Plasma consists of neutral and excited atoms, free radicals, negative and positive ions, UV photons with net electric charge zero. Bogaerts et al.
[2] reported that the plasma is divided into high temperature (local thermal equilibrium) and low temperature (non-local thermal equilibrium). The cold plasma contains low temperature particles like neutral molecules, atomic species and relatively high temperature electrons because of this the plasma is cold and does not affect the sensitive materials which comes into contact [3]. Ling et al. [4] stated that cold plasma treatment is thought to be a fast, economic and pollution-free method to improve seed performance, plant growth and ultimately plant production.

The cold plasma treatment of seeds has a synergistic effects i.e. it acts as antimicrobial agent (ability to kill wide range of microbes) and enhance the seed germination and plant growth. Till date there are many reviews on the antimicrobial effects of cold plasma treatment but only few reviews on the seed germination enhancement. The aim of the present review is to give some insights on the seed germination enhancement by the cold plasma treatment.

\section{Seed germination effect of cold plasma}

Sirova et al. [5] reported that the seedling growth during germination involves two key steps 1) primary cell elongation of the axial part of the embryo, and 2) simultaneous or delayed 
cell division in the radicle meristem. Ji et al. [6] reported that the seed germination is initiation of embryo breaking the dormant stage and always start with imbibition of water. Seed germination activity involves several physiological and biochemical changes such as protein synthesis, enzyme activation and starch metabolisms [7]. The authors have also reported that the seed germination always hindered by seed dormancy factors which is undesirable process. The cold plasma can be applied by two different ways

I. Direct treatment of seeds,

II. Indirectly treating the seeds with plasma activated water (PAW) or plasma acid.

\section{Direct treatment}

In direct treatment method the seeds are directly placed in between the electrodes or placed under the plasma regime like in plasma jets. Direct exposure of chickpea seeds to atmospheric cold air plasma for 5 min by Mitra et al. [8] observed an overall increase in seed germination by $89.2 \%$. The authors have reported that the increase in the seed conductivity and seed roughness after the plasma treatment is the main reason for enhancement. The increase in seed roughness or etching caused by bombardment of reactive species may be the reason for increase in hydrophilicity of seeds. Thirumdas et al. [9] reported that the radio frequency low pressure plasma treatment of brown rice increased the hydrophilicity. Plasma etching is the removal of volatile substrates removed by chemical reactions and/or physical means (ion bombardment) and which are carried away in the gas stream. An investigation carried out by Bormashenko et al. [10] on the wettability of seeds using cold air plasma decreased the contact angle was from $115^{\circ}$ to $0^{\circ}$.The plasma treatment resulted in complete hydrophilicity of seeds. The water imbibition of plasma treated seeds was increased by $30 \%$ after the $12 \mathrm{~h}$ of germination.

Dubinov et al. [11] exposed barely seeds to both continuous and pulsed glow discharge plasmas, with a pulse repetition rate of $0.5 \mathrm{~Hz}$ and pulse duration of $150-200 \mathrm{~ms}$ in air under $0.1-0.2 \mathrm{~Pa}$.

Table 1: Key findings of different studies conducted on the seed germination rate using cold plasma technology.

\begin{tabular}{|c|c|c|c|c|}
\hline Seeds & Plasma Source & Feed Gas & Key Findings & References \\
\hline Rapeseed & DBD plasma & Argon & $\begin{array}{l}\text { No change in the germination } \\
\text { rate. Increase in seed viability was } \\
\text { observed }\end{array}$ & $\begin{array}{l}\text { Schnabel et al. } \\
\text { [23] }\end{array}$ \\
\hline Pea & $\begin{array}{l}\text { Diffuse coplanar surface } \\
\text { barrier discharge }\end{array}$ & Air & $\begin{array}{l}\text { Increase in germination percentage, } \\
\text { root length, shoot length, seed vigor }\end{array}$ & $\begin{array}{l}\text { Stolarik et al. } \\
\qquad[24]\end{array}$ \\
\hline $\begin{array}{l}\text { Herbaceous } \\
\text { plant }\end{array}$ & DBD plasma & Air & $\begin{array}{c}\text { Permeability of the seeds was } \\
\text { improved significantly, acceleration } \\
\text { of seed germination and seedling } \\
\text { emergence }\end{array}$ & Jiayun et al. [25] \\
\hline $\begin{array}{l}\text { Radish } \\
\text { sprout }\end{array}$ & $\begin{array}{l}\text { atmospheric pressure } \\
\text { plasma torch }\end{array}$ & Oxygen & $\begin{array}{l}\text { Enhancement of the germination } \\
\text { and lengths of the stem and root of } \\
\text { plants are observed after seeding }\end{array}$ & $\begin{array}{l}\text { Hayashi et al. } \\
\qquad[26]\end{array}$ \\
\hline
\end{tabular}

The authors reported that the number of germinated seeds after the exposure was increased more than $27 \%$ after the 5 th day of germination. Low pressure plasma treatment of mung beans with a radio frequency $(13.56 \mathrm{MHz})$ significantly enhanced the germination rate by $36.2 \%$, radicle root length by $20 \%$ and conductivity of seeds by $102 \%$ when compared to the untreated samples.

A detailed study conducted by Ji et al. [7] on germination of coriander seeds using nitric oxide (NO) gas produced from microwave plasma torch and explained all the possible ways for increase in seed germination rate. The authors have observed $91-97 \%$ germination of seeds after treatment whereas only $60 \%$ in the case of control/untreated seeds. The treated seeds showed longer radicals and stems length compared to control seeds. The NO formed in the plasma serve as a signaling pathway, triggers activation of several biological processes and a crucial regulator for cellular activation. The authors finally concluded their argument that the NO formed in the plasma is responsible for seed germination enhancement. A similar explanation was given by Zhang et al. [12] on the synergistic effect of formation of endogenous NO radicals and breakdown of seed dormancy

Violleau et al. [13] reported that the oxygen plasma treatment of corn seeds increased the germination rate and higher yields. Another study conducted by Puligundla et al. [14] on effect of corona discharge plasma jet on sprouting of rapeseeds. Exposure of rapeseeds for $1 \mathrm{~min}$ increased the germination rate by $7.7 \%$ compared to untreated seeds. The authors have reported that exposure of seeds resulted in scarification; formation of deep longitudinal cracks on the seed surface, increase in surface area attributing to increase in surface energy. Sera et al. [15] studied the effect of cold plasma on seed germination of oat corns and wheat at 500W at different time durations. The authors have observed that plasma treatment did not affect the germination of oats but there is slight increase in germination rate in wheat. the treatment with static magnetic fields [16]. Table 1 report on the different seeds enhancement caused by cold plasma. resulted in increase in higher germination rates. Similar increase in the germination rate of rice was observed after 


\begin{tabular}{|c|c|c|c|c|}
\hline Tomato & Arc discharge Plasma & Air & $\begin{array}{c}\text { In pot experiments the yield is } \\
\text { increased by } 20.7 \% \text {. Sprouting } \\
\text { rate after the treatment is } 32.75 \% \text {, } \\
\text { whereas the untreated was only } \\
4.75 \%\end{array}$ & $\begin{array}{l}\text { Meiqiang et al. } \\
\text { [27] }\end{array}$ \\
\hline Wheat & $\begin{array}{l}\text { Atmospheric pressure } \\
\text { surface discharge }\end{array}$ & Air & $\begin{array}{l}\text { Plasma had little effect on } \\
\text { germination rate but the } \\
\text { distribution of roots was shifted } \\
\text { towards higher lengths as } \\
\text { compared to untreated samples }\end{array}$ & Dobrin et al. [11] \\
\hline Rapeseed & $\begin{array}{l}\text { Radio frequency } \\
\text { discharge }\end{array}$ & Helium & $\begin{array}{l}\text { Significant improvement in } \\
\text { germination rate by } 6.25 \% \text { in } \\
\text { drought sensitive variety, and } \\
4.44 \% \text { in drought tolerant variety }\end{array}$ & Ling et al. [4] \\
\hline Soybean & $\begin{array}{l}\text { Radio frequency } \\
\text { discharge }\end{array}$ & Helium & $\begin{array}{c}\text { Germination and vigor indices } \\
\text { significantly increased by } 14.66 \% \\
\text { and } 63.33 \% \text {, respectively. Water } \\
\text { uptake improved by } 14.03 \%\end{array}$ & Ling et al. [28] \\
\hline Mung beans & $\begin{array}{l}\text { Radio frequency } \\
\text { capacitively coupled } \\
\text { plasma }\end{array}$ & Air & $\begin{array}{l}\text { Increase in following parameters- } \\
\text { germination rate by } 36.2 \% \text {,radicle } \\
\text { root length by } 20 \% \text { and } \\
\text { conductivity of seeds by } 102 \%\end{array}$ & Sadhu et al. 2017 \\
\hline $\begin{array}{l}\text { Coriander } \\
\text { seeds }\end{array}$ & DBD & Nitrogen & $\begin{array}{l}\text { After } 7 \text { days of germination there is } \\
90 \% \text { of seed germination compared } \\
\text { to } 40-60 \% \text { for control seeds }\end{array}$ & Ji et al. [7] \\
\hline
\end{tabular}

\section{Indirect treatment}

In this type of treatments the seeds are treated with plasma activated water (PAW). The PAW is generated by application of cold plasma on the water surface or underneath water using different plasma sources. Shen et al. [17] reported that based on the working gas, discharge type and chemical composition of plasma several reactions are initiated in the water resulting in primary and secondary reactive species changing the physicochemical properties of water. The important reactive species formed in the PAW are reactive oxygen species (ROS) like atomic oxygen, singlet oxygen, superoxide, hydroxyl radicals and reactive nitrogen species (RNS) like peroxynitrite, nitric oxide, nitrates and nitrite ions. The formation of these reactive species attributes some important change in properties of water are $\mathrm{pH}$, oxidation-reduction potential, conductivity, $\mathrm{H} 2 \mathrm{O} 2$ concentration, nitrites and nitrates concentration.
Naumova et al. [18] conducted a study on underwater electric front type discharge to generate PAW and treatment of PAW on rye seeds. The rye seeds treatment with PAW for $5 \mathrm{~min}$ increased the germinability by $50 \%$ and the number of seeds germinated. Along with the hormones, the ROS and NO radicals participate in several signalling pathways involved in the seed germination [19]. The studies related to germination suggested that the ROS including superoxide, hydroxyl radicals, hydrogen peroxide and atomic oxygen are responsible for seed germination [20]. An investigation carried out by Ji et al. [6] on the seed germination of spinach observed a slight increase in germination rate after treating with DBD N2 plasma. The authors have also reported increase in level of GA3 hormone and mRNA expression of an amylolytic enzyme related gene expression in seeds. Sirova et al. [5] reported that the reactive nitrogen species (RNS) particularly NO can break the seed dormancy and enhance the seed germination.
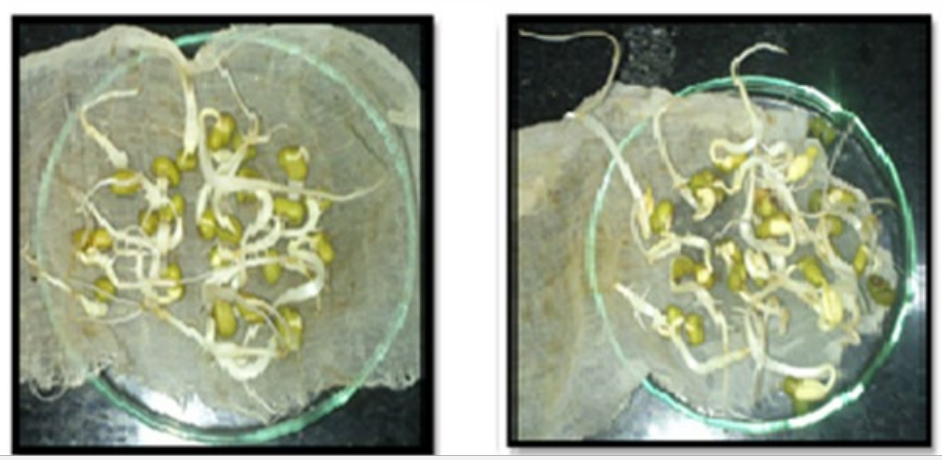

Figure 1: Response surface and contour plot showing the interactive effect of glycerol concentration on the nitrilase activity. 
A study conducted by Sivachandiran \& Khacef [21] on the effect of PAW (generated using cylindrical double DBD (Cyl-DBD) reactor and tap water on seed germination. The authors have observed $60 \%$ and $100 \%$ germination rate when seeds treated with PAW-15 and PAW-30 respectively along with improved seedling growth whereas only $40 \%$ with tap water. They have stated that the increase in nitrate ion concentration is the main reason for obtaining higher germination rates. Takaki et al. [22] reported that the nitrate species formed in PAW served as a fertilizer which resulted in enhanced growth. The activation of tap water with the atmospheric plasma jet increased the germination rate of lentil seeds to $80 \%$ compared to $30 \%$ of untreated seeds (Table 1) [23-28].

\section{Conclusion}

It can be concluded from the reports of several researchers that the seed germination rate enhancement is achieved from cold plasma technology. The plasma etching or scratching effect on the seed coat increased the hydrophilicity of seeds. Few authors have reported that few reactive species formed in the plasma has the ability to breakdown the seed dormancy and increased the seed germination rate. But a detailed studied on the formation of different reactive species formed in the plasma needs to be carried out. Cold plasma can be considered as the alternative technology for enhancement of seed germination rate and plant yield.

\section{References}

1. Filatova I, Azharonok V, Kadyrov M, Beljavsky V, Gvozdov A, et al. (2011) The effect of plasma treatment of seeds of some grains and legumes on their sowing quality and productivity. Roman Journal of Physics 56: 139-143.

2. Bogaerts A, Neyts E, Gijbels R, Van der Mullen J (2002) Gas discharge plasmas and their applications. Spectrochimica Acta Part B: Atomic Spectroscopy 57(4): 609-658.

3. Thirumdas R, Trimukhe A, Deshmukh RR, Annapure US (2017) Functional and rheological properties of cold plasma treated rice starch. Carbohydrate Polymers 157: 1723-1731.

4. Ling L, Jiangang L, Minchong S, Chunlei Z, Yuanhua D (2015) Cold plasma treatment enhances oilseed rape seed germination under drought stress. Scientific Reports 5: 13033.

5. Š́rová J, Sedlářová M, Piterková J, Luhová L, Petřivalský M (2011) The role of nitric oxide in the germination of plant seeds and pollen. Plant Science 181(5): 560-572.

6. Ji SH, Choi KH, Pengkit A, Im JS, Kim JS, et al. (2016) Effects of high voltage nanosecond pulsed plasma and micro DBD plasma on seed germination, growth development and physiological activities in spinach. Archives of biochemistry and biophysics 605: 117-128.

7. Ji SH, Kim T, Panngom K, Hong YJ, Pengkit A, et al. (2015) Assessment of the Effects of Nitrogen Plasma and Plasma-Generated Nitric Oxide on Early Development of Coriandum sativum. Plasma Processes and Polymers 12(10): 1164-1173.

8. Mitra A, Li YF, Klämpfl TG, Shimizu T, Jeon J, et al. (2014) Inactivation of surface-borne microorganisms and increased germination of seed specimen by cold atmospheric plasma. Food and Bioprocess Technology 7(3): 645-653.
9. Thirumdas R, Saragapani C, Ajinkya MT, Deshmukh RR, Annapure US (2016) Influence of low pressure cold plasma on cooking and textural properties of brown rice. Innovative Food Science \& Emerging Technologies 37: 53-60.

10. Bormashenko E, Grynyov R, Bormashenko Y, Drori E (2012) Cold radiofrequency plasma treatment modifies wettability and germination speed of plant seeds. Scientific reports 2: 741.

11. Dobrin D, Magureanu M, Mandache NB, Ionita MD (2015) The effect of non-thermal plasma treatment on wheat germination and early growth. Innovative Food Science \& Emerging Technologies 29: 255260.

12.Zhang S, Rousseau A, Dufour T (2017) Promoting lentil germination and stem growth by plasma activated tap water, demineralized water and liquid fertilizer. RSC Advances 7(50): 31244-31251.

13. Violleau F, Hadjeba K, Albet J, Cazalis R, Surel O (2008) Effect of oxidative treatment on corn seed germination kinetics. Ozone: Science and Engineering 30(6): 418-422.

14. Puligundla P, Kim JW, Mok C (2017) Effect of corona discharge plasma jet treatment on decontamination and sprouting of rapeseed (Brassica napus L.) seeds. Food Control 71: 376-382.

15. Sera B, Spatenka P, Sery M, Vrchotova N, Hruskova I (2010) Influence of plasma treatment on wheat and oat germination and early growth. IEEE Transactions on Plasma Science 38(10): 2963-2968.

16. Carbonell MV, Martinez E, Amaya JM (2000) Stimulation of germination in rice (Oryza sativa L.) by a static magnetic field. Electro-and magnetobiology 19(1): 121-128.

17. Shen J, Tian Y, Li Y, Ma R, Zhang Q et al. (2016) Bactericidal effects against $\mathrm{S}$. aureus and physicochemical properties of plasma activated water stored at different temperatures. Scientific reports 6: 28505 .

18. Naumova IK, Maksimov AI, Khlyustova AV (2011) Stimulation of the germinability of seeds and germ growth under treatment with plasmaactivated water. Surface Engineering and Applied Electrochemistry 47(3): 263-265.

19. El-Maarouf-BH, Bailly C (2008) Oxidative signaling in seed germination and dormancy. Plant Signaling \& Behavior 3(3): 175-182.

20.Su L, Lan Q, Pritchard HW, Xue H, Wang X (2016) Reactive oxygen species induced by cold stratification promote germination of Hedysarum scoparium seeds. Plant Physiology and Biochemistry 109: 406-415.

21. Sivachandiran L, Khacef A (2017) Enhanced seed germination and plant growth by atmospheric pressure cold air plasma: combined effect of seed and water treatment. RSC Advances 7(4): 1822-1832.

22. Takaki K, Takahata J, Watanabe S, Satta N, Yamada O, et al. (2013) Improvements in plant growth rate using underwater discharge. In Journal of Physics: Conference Series 418(1): 012140.

23. Schnabel U, Niquet R, Krohmann U, Winter J, Schlüter O, et al. (2012) Decontamination of microbiologically contaminated specimen by direct and indirect plasma treatment. Plasma Processes and Polymers 9(6): 569-575.

24. Stolárik T, Henselová M, Martinka M, Novák O, Zahoranová A, et al. (2015) Effect of low-temperature plasma on the structure of seeds, growth and metabolism of endogenous phytohormones in pea (Pisum sativum L.). Plasma Chemistry and Plasma Processing 35(4): 659-676.

25. Jiayun T, Rui H, Xiaoli Z, Ruoting Z, Weiwen C, et al. (2014) Effects of atmospheric pressure air plasma pretreatment on the seed germination and early growth of Andrographis paniculata. Plasma Science and Technology 16(3): 260. 
26. Hayashi N, Ono R, Shiratani M, Yonesu A (2015) Antioxidative activity and growth regulation of Brassicaceae induced by oxygen radical irradiation. Japanese Journal of Applied Physics 54(6S2): 06GD01.

27. Meiqiang Y, Mingjing H, Buzhou M, Tengcai M (2005) Stimulating effects of seed treatment by magnetized plasma on tomato growth and yield. Plasma Science and Technology 7(6): 3143.
28. Ling L, Jiafeng J, Jiangang Li, Minchong S, Xin H, et al. (2014) Effects of cold plasma treatment on seed germination and seedling growth of soybean. Scientific Reports 4: 5859.
This work is licensed under Creative

Commons Attribution 4.0 License

DOI:10.19080/ARTOAJ.2018.13.555874
Your next submission with Juniper Publishers will reach you the below assets

- Quality Editorial service

- Swift Peer Review

- Reprints availability

- E-prints Service

- Manuscript Podcast for convenient understanding

- Global attainment for your research

- Manuscript accessibility in different formats

(Pdf, E-pub, Full Text, Audio)

- Unceasing customer service

Track the below URL for one-step submission https://juniperpublishers.com/online-submission.php 